\title{
Acetylcholine Acts through Nicotinic Receptors to Enhance the Firing Rate of a Subset of Hypocretin Neurons in the Mouse Hypothalamus through Distinct Presynaptic and Postsynaptic Mechanisms ${ }^{1,2}$
}

\author{
Wen-Liang Zhou, Xiao-Bing Gao, and \Marina R. Picciotto
}

DOI:http://dx.doi.org/10.1523/ENEURO.0052-14.2015

Departments of Psychiatry and Comparative Medicine, Kavli Insitute for Neuroscience, Yale University School of Medicine, New Haven, Connecticut 06508

\begin{abstract}
Hypocretin/orexin neurons regulate many behavioral functions, including addiction. Nicotine acts through nicotinic acetylcholine receptors ( $\mathrm{nAChRs)}$ to alter firing rate of neurons throughout the brain, leading to addictionrelated behaviors. While nAChRs are expressed in the hypothalamus and cholinergic fibers project to this structure, it is unclear how acetylcholine modulates the activity of hypocretin neurons. In this study, we stimulated hypocretin neurons in mouse brain slices with ACh in the presence of atropine to dissect presynaptic and postsynaptic modulation of these neurons through nAChRs. Approximately one-third of tested hypocretin neurons responded to pressure application of $A C h(1 \mathrm{mM})$ with an increase in firing frequency. Stimulation of postsynaptic nAChRs with ACh or nicotine resulted in a highly variable inward current in approximately one-third of hypocretin neurons. In contrast, ACh or nicotine $(1 \mu \mathrm{M})$ reliably decreased the frequency of miniature EPSCs (mEPSCs). Antagonism of nAChRs with mecamylamine also suppressed mEPSC frequency, suggesting that an endogenous, tonic activation of presynaptic $n A C h R s$ might be required for maintaining functional mEPSC frequency. Antagonism of heteromeric $(\alpha 4 \beta 2)$ or homomeric $(\alpha 7)$ nAChRs alone suppressed mEPSCs to a lesser extent. Finally, blocking internal calcium release reduced the frequency of mEPSCs, occluding the suppressive effect of presynaptic ACh. Taken together, these data provide a mechanism by which phasic ACh release enhances the firing of a subset of hypocretin neurons through postsynaptic nAChRs, but disrupts tonic, presynaptic nAChR-mediated glutamatergic inputs to the overall population of hypocretin neurons, potentially enhancing the signal-to-noise ratio during the response of the nAChR-positive subset of neurons.
\end{abstract}

Key words: acetylcholine; hypocretin; nicotine; presynaptic

\section{Introduction}

A small group of neurons that express hypocretin $(\mathrm{Hcrt}$, also known as orexin) resides in the perifornical and lateral

Received November 6, 2014; accepted February 5, 2015; First published February 12, 2015.

${ }^{1}$ The authors declare no competing financial interests.

${ }^{2}$ Author contributions: W.-L.Z., X.-B.G., and M.R.P. designed research; W.-L.Z. performed research; W.-L.Z. and X.-B.G. analyzed data; W.-L.Z., X.-B.G., and M.R.P. wrote the paper.

Acknowledgements: This work was supported by the Kavli Institute for Neuroscience at Yale and Grant DA14241 from the National Institutes of Health. hypothalamus (de Lecea et al., 1998; Sakurai et al., 1998), and these neurons project throughout the brain and spinal cord (Peyron et al., 1998; van den Pol, 1999; Bayer et al., 2002). Hcrt+ neurons play important roles in modulating

Correspondence should be addressed to Marina R. Picciotto, Department of Psychiatry, Yale University School of Medicine, 34 Park Street, 3rd Floor Research, New Haven, CT 06508. E-mail: marina.picciotto@yale.edu.

DOI:http://dx.doi.org/10.1523/ENEURO.0052-14.2015

Copyright () 2015 Zhou et al.

This is an open-access article distributed under the terms of the Creative Commons Attribution 4.0 International, which permits unrestricted use, distribution and reproduction in any medium provided that the original work is properly attributed. 


\section{Significance Statement}

Neurons expressing the neuropeptide hypocretin regulate many behavioral functions, including sleep, motivation, and behaviors related to addiction. The ability of nicotine to stimulate nicotinic acetylcholine receptors (nAChRs) is essential for its addictive properties, but little is known about whether, and how, nicotine and the endogenous neurotransmitter acetylcholine affect hypocretin neurons. This study suggests that phasic acetylcholine release can enhance the firing of a subset of hypocretin neurons through postsynaptic $n A C h R s$, while disrupting tonic activation of presynaptic nAChRs necessary for maintaining functional glutamatergic inputs to hypocretin neurons. We propose that this mechanism could enhance the signal-to-noise ratio of the electrical response to nicotine or acetylcholine in the nAChR-positive subset of neurons.

multiple behaviors, including circadian rhythmicity (Mileykovskiy et al., 2005), appetite and food intake (Sakurai et al., 1998; Wu et al., 2002), arousal (Boutrel et al., 2010), goal-oriented behaviors (Boutrel et al., 2005), and emotions (Blouin et al., 2013). In addition, a number of studies implicate hypocretin signaling in the rewarding and addictive properties of drugs of abuse (Mahler et al., 2012; Rao et al., 2013; Muschamp et al., 2014), including nicotine (Hollander et al., 2008).

Nicotine addiction is mediated by nicotinic acetylcholine receptors (nAChRs). Histochemical studies have shown that nAChRs are also expressed in hypothalamus (Avissar et al., 1981; Wada et al., 1989; O'Hara et al., 1998). Specifically, Hcrt+ neurons receive appreciable cholinergic innervation arising from basal forebrain (Sakurai et al., 2005; Henny and Jones, 2006), which indicates that the activity of Hcrt+ neurons might be modulated by nAChRs. nAChRs are pentameric, non-selective cation channels. Activation of nAChRs results in a physiological net flow of inward current, which directly depolarizes the cell and generally affects neuronal input and/or output, influencing subsequent behaviors. nAChRs may be located both presynaptically and postsynaptically. Stimulation of these receptors is known to increase neurotransmitter release, and can also depolarize the postsynaptic neuron (Gioanni et al., 1999; Mansvelder et al., 2002; Lambe et al., 2003). Previous studies have shown that nicotine can alter the firing of Hcrt+ neurons in rat as measured by c-fos immunoreactivity (Pasumarthi et al., 2006; Pasumarthi and Fadel, 2008), but it is not known whether nAChRs are expressed on these neurons, whether the effects on c-fos immunoreactivity were due to postsynaptic signaling, presynaptic signaling, or network changes due to changes in other neuronal subtypes. Since the ability of nicotine to alter hypocretin signaling may be important for its addiction liability (Hollander et al., 2008), it is important to understand the cellular mechanisms underlying these physiological effects.

To investigate the effect of $n A C h R$ stimulation on function of the hypocretin system, we first investigated how acetylcholine (ACh) in the presence of atropine affects spontaneous action potential firing, which is a measure of nicotinic influence on the output of Hcrt+ neurons. Next, we separated presynaptic and postsynaptic modulation by $\mathrm{ACh}$ and nicotine using synaptic blockers, and used pressure application (puff) or fast pipetting of drugs to identify electrophysiological changes following the stimulation of nAChRs. A transient puff of ACh or nicotine at high concentration was used to mimic phasic transmission to determine the postsynaptic response (Alexander et al., 2009). nAChRs can increase release of glutamate from presynaptic terminals in several brain areas, including the ventral tegmental area (Mansvelder et al., 2002) and the prefrontal cortex (Gioanni et al., 1999; Lambe et al., 2003). To assess the effects of cholinergic transmission on the basal level of presynaptic glutamatergic transmission, spontaneous miniature EPSCs (mEPSCs) were recorded following a puff of ACh as well as in response to bath-applied nicotine at a concentration that mimics brain levels during smoking. We show that the activity of both Hcrt+ neurons and the presynaptic glutamatergic terminals projecting to these cells is modulated by $\mathrm{nAChR}$ signaling in a manner that appears to enhance the output of a subset of Hcrt+ neurons during phasic ACh signaling.

\section{Materials and Methods}

\section{Animals}

Male and female adult Hcrt-GFP mice (Li et al., 2002) (2-5 months old, backcrossed onto the C57BL6/J genetic background for at least 10 generations) were group housed and maintained on a 12-12 h light-dark cycle with food and water available ad libitum. Use of animals was in strict accordance with $\mathrm{NIH}$ Care and Use of Laboratory Animals Guidelines.

\section{Brain slice and electrophysiology}

Briefly, mouse brains were harvested following acute decapitation. Brains were immediately immersed in ice cold, oxygenated artificial cerebrospinal fluid (ACSF). ACSF contained (in mM): $125 \mathrm{NaCl}, 26 \mathrm{NaHCO}_{3}, 10$ glucose, $2.3 \mathrm{KCl}, 1.26 \mathrm{KH}_{2} \mathrm{PO}_{4}, 2 \mathrm{CaCl}_{2}$ and $1 \mathrm{MgSO}_{4}, \mathrm{pH}$ 7.4. After being trimmed to a small tissue block containing the hypothalamus, brain chunks were cut on a vibratome into coronal slices $(300 \mu \mathrm{m})$. Acute slices were incubated in a holding chamber with protective NMDG ACSF (containing (in $\mathrm{mM}$ ): $110 \mathrm{~N}$-methy-D-glucamine, $110 \mathrm{HCl}, 2.5$ $\mathrm{KCl}, 1.2 \mathrm{NaH}_{2} \mathrm{PO}_{4}, 25 \mathrm{NaHCO}_{3}, 25$ glucose, $10 \mathrm{MgSO}_{4}$, $0.5 \mathrm{CaCl}_{2}, \mathrm{pH} \mathrm{7.4)}$ at $36^{\circ} \mathrm{C}$ for $30 \mathrm{~min}$, then transferred to regular ACSF and maintained at room temperature (ac- 
cording to the method described in http://www.brainslicemethods.com).

All experimental measurements were performed at 32$34^{\circ} \mathrm{C}$. Whole-cell recordings were made from visuallyidentified, GFP-positive neurons in hypothalamus under voltage (holding $V=-60 \mathrm{mV}$ ) or current clamp configuration. Electrical signals were amplified with a Multiclamp 700B and digitized with Digidata 1440A (Molecular Devices). Micropipettes with a tip resistance of 4-7 M $\Omega$ were made of borosilicate glass (Warner Instruments) using a Sutter micropipette puller (P-97) and back filled with an intracellular solution containing (in $\mathrm{mM}$ ): $135 \mathrm{~K}$-gluconate, $2 \mathrm{MgCl}_{2}, 10 \mathrm{Na}_{2}$-phosphocreatine, $3 \mathrm{Na}_{2}$-ATP, $0.3 \mathrm{Na}_{2}$ GTP, and 10 HEPES (pH 7.3). Only recordings with stable series resistance $(<30 \mathrm{M} \Omega)$ were analyzed.

\section{Drug application}

All drugs were dissolved in ACSF. For bath perfusion, D-2-amino-5-phosphonovalerate (AP-5), 6-cyano-7nitroquinoxaline-2, 3-dione disodium (CNQX), picotoxin (PTX), tetrodotoxin citrate (TTX), and atropine (Sigma) were dissolved in ACSF at their final concentration. For focal pressure application (puff), acetylcholine $(1 \mathrm{mM})$ or nicotine $(100 \mu \mathrm{M})$ was loaded into a glass micropipette $(2-4 \mathrm{M} \Omega)$, and the pipette tip positioned $40-50 \mu \mathrm{m}$ from the cell body. Drug solutions were pressure-ejected via a computer-driven picospritzer (puff duration: $5 \mathrm{~s}$ ) during the electrical recording. The picospritzer was used to control the pressure, timing, and duration of the puff. For fast bath application, $200 \mu \mathrm{L}$ of nicotine $(5 \mu \mathrm{M})$, mecamylamine $(50 \mu \mathrm{M})$, dihydro- $\beta$-erythroidine hydrobromide $(50 \mu \mathrm{M})$, methyllycaconitine $(50 \mathrm{nM})$, dantrolene (250 $\mu \mathrm{M})$, and (-)-xestospongin $\mathrm{C}(25 \mu \mathrm{M})$ were pipetted into the recording chamber ( $1 \mathrm{~mL}$ of volume), at $5 \times$ final concentration, carefully along the chamber wall slope.

\section{Data analysis}

Electrical recording data of nAChR currents were analyzed using Clampfit 10 (Molecular Devices). Traces were filtered with Gaussian low-pass with $50 \mathrm{~Hz}$ cutoff before current amplitude measurements. Other electrical data were analyzed using Axograph X 1.5.5 (Axograph Scientific). To analyze miniature EPSCs, we took $150-200$ events for baseline and washout from each cell, during a time period ranging from 60 to $120 \mathrm{~s}$. For Ach, we took all events from within $90 \mathrm{~s}$ after application of ACh. Traces were filtered with Gaussian low-pass with $500 \mathrm{~Hz}$ cutoff before event searching. A template EPSC was defined with amplitude $-20 \mathrm{pA}$, rise $0.5 \mathrm{~ms}$, and decay $3 \mathrm{~ms}$, and only those EPSCs with amplitude $\geq-10 \mathrm{pA}$ were counted. Following programmed event detection, all events were examined by eye to be counted as EPSCs. All statistics were done on raw data. Unpaired Student's $t$ tests and chi square $\left(\chi^{2}\right)$ test were used for determining statistically difference. Significance was set as $p<0.05$, and high significance as $p<0.01$. Values are presented as mean \pm SEM.

\section{Results}

\section{Nicotinic stimulation boosts spontaneous action potential firing in hypocretin neurons}

To determine whether phasic nicotinic stimulation modulates the electrical output of Hcrt+ neurons, we patched the cells with an ATP-rich $(5 \mathrm{mM}$, vs $3 \mathrm{mM}$ in other experiments) intracellular solution and investigated the effect of pressure-applied ACh on spontaneous action potential firing. An adequate level of intracellular ATP is required for normal Hcrt+ neuron function (Liu et al., 2011), potentially because Hcrt + neurons are involved in the regulation of energy status (Girault et al., 2012; Gao and Horvath, 2014). In the presence of atropine, Hcrt+ neurons regularly fired action potentials. Mechanical interference as a result of puffing bath solution induced a temporary reduction in firing frequency $(<50 \%$ of baseline) in 7 out of 11 cells (Fig. 1B1,C), despite inducing no, or minimal, outward current ( $<10 \mathrm{pA}$, data not shown). Firing in 4 out of 11 cells was not altered by puffing bath solution $(50 \%<$ change $<200 \%$ at $0-10$ s). In contrast, in 7 out of 20 cells, a puff of ACh ( $1 \mathrm{mM})$ increased the firing rate ( $>200 \%$ of baseline) with a significant depolarization of the membrane potential (Fig. 1B2,D). We note that this experimental design is not suitable to detect decreases in firing due to presynaptic mechanisms. Only blocking all mEPSCs using CNQX+AP-5 induces even a small change in firing rate of a hypocretin neuron $(\sim 2 \mathrm{~Hz}$ to $\sim 1.6 \mathrm{~Hz}$; Li et al, 2002), which is not distinguishable using the current criteria $(50 \%<$ change $<200 \%)$. In nine cells, an ACh puff decreased the firing rate, and in four cells the ACh puff had no effect. Thus, stimulation of nAChRs depolarizes approximately one-third of Hcrt+ neurons and boosts the action potential firing of these cells.

To identify the receptor type(s) that mediate this depolarization and increase in firing rate, we applied an ACh puff in the presence of the heteromeric $(\alpha 4 \beta 2)$ nAChR antagonist, dihydro- $\beta$-erythroidine $(\mathrm{DH} \beta \mathrm{E})$, or the homomeric $(\alpha$ 7) nAChR antagonist, methyllycaconitine (MLA). When applied alone, $\mathrm{DH} \beta \mathrm{E}$ significantly decreased the firing rate by $62.9 \%(p=0.00027)$ at $10 \mu \mathrm{M}$, whereas MLA did not change the firing rate of Hcrt + neurons at a concentration of $10 \mathrm{nM}$ (Fig. 2, top; $20-30 \mathrm{~s}$ after puff vs $10-20 \mathrm{~s}$ before puff: $p=0.58$ ). However, after addition of either reagent, most cells recovered to a new stable firing state that lasted for several minutes with attachment of the recording pipette (Fig. 2, bottom). $\mathrm{DH} \beta \mathrm{E}(10 \mu \mathrm{M})$ significantly reduced the ability of $A C h$ to increase firing in 11 of $11 \mathrm{Hcrt}+$ neurons $\left(\chi^{2}\right.$ test, $\left.p=0.0069\right)$ and increased the likelihood that an ACh puff could decrease the firing rate $(p=6.8 \mathrm{E}-6,10-20 \mathrm{~s}$ after puff; Fig. 1E). In contrast, although MLA (10 nM) antagonized the effects of an ACh puff in the majority of Hcrt+ neurons, ACh still increased the firing rate in 2 of 16 cells in the presence of the homomeric $\mathrm{nAChR}$ antagonist $\left(\chi^{2}\right.$ test, $p=0.00039$; Fig. $1 F)$. In this data set, some cells increased their firing rate during the ACh puff and returned to normal right after puff cessation, whereas 10 of 17 cells responded with a prolonged period of firing increase. These prolonged periods 

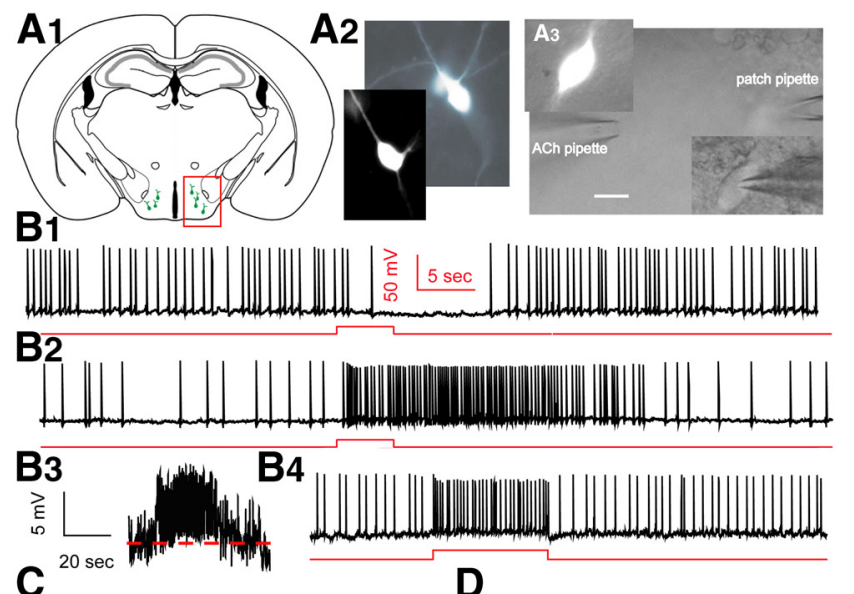

C
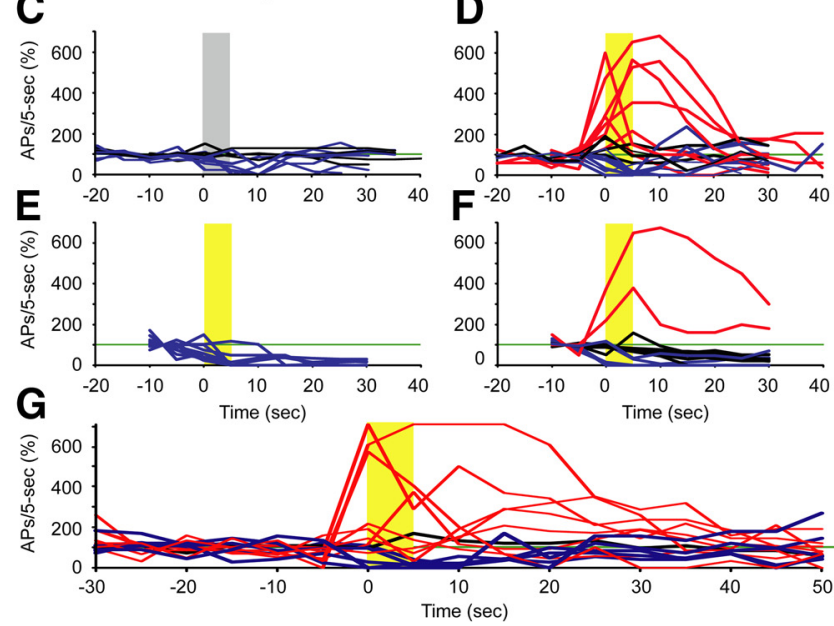

Figure 1 Cholinergic stimulation by ACh boosts spontaneous action potential firing in Hcrt+ neurons. $\boldsymbol{A}_{1}$, Sketch of a brain slice showing Hcrt+ neurons (green cells in the red box) residing in the hypothalamus. $\boldsymbol{A}_{2}$, Morphology of two Hcrt+ neurons shown in the fluorescent channel. $\boldsymbol{A}_{3}$, Differential Interference Contrast video-microscopy showing the experimental paradigm of pressure application (puff) of drug onto the soma and proximal processes, while keeping the patch onto the neuron. Scale bar, $10 \mu \mathrm{m}$. $\boldsymbol{B}_{1}$, Mechanical interference (puff of bath solution) frequently produces a temporary depression of spontaneous firing. $\boldsymbol{B}_{2}$, In the presence of atropine $(4 \mu \mathrm{M})$, application of ACh $(1 \mathrm{mM})$ boosts action potential firing for tens of seconds. $\boldsymbol{B}_{\boldsymbol{3}}$, The same trace as in $\boldsymbol{B}_{\mathbf{2}}$, except on a different scale and filtered with Gaussian low pass $5 \mathrm{~Hz}$. $\boldsymbol{B}_{\mathbf{4}}$, Injection of $+10 \mathrm{pA}$ of current into the Hcrt + neuron notably increases the firing frequency. Red lines represent the timing and duration of ACh application or current injection. $\boldsymbol{C}$, Mechanical interference does not affect firing ( $n=4 / 11$ cells), or results in a temporary depression of firing $(n=7 / 11$ cells). $\boldsymbol{D}$, Differential responses to the puff of ACh. In 7 out of 20 cells, firing was enhanced by ACh, 4 out of 20 cells were not affected, while 9 out of 20 cells were inhibited. $\boldsymbol{E}$, With $\mathrm{DH} \beta \mathrm{E}$ in the bath, $\mathrm{ACh}$ did not increase firing of any Hcrt+ neurons tested ( $n=11 / 11$ cells). $\boldsymbol{F}$, With MLA in the bath, a puff of ACh boosted firing in 2 of 16 cells, had no effect in 9 of 16 cells, and decreased firing in 5 of 16 cells. The gray bar indicates the time duration of ACSF application; yellow bars indicate the time duration of ACh application. $\boldsymbol{C}-\boldsymbol{F}$, All experiments were conducted in the presence of atropine. $\mathbf{G}$, The responses of $\mathrm{Hcrt}+$ neurons to ACh in absence of atropine. In 8 out of 14 cells, firing was enhanced by ACh, in 1 out of 14 cells firing was unaffected, while in 5 out of 14 cells firing was inhibited. of firing may be due to increased activity of Hcrt neurons triggering action potentials in a recurrent circuit.

Muscarinic acetylcholine receptors (mAChRs) are expressed by $\sim 30 \%$ of hypocretin neurons (Sakurai et al., 2005), and may contribute significantly to cholinergic modulation of these cells. To determine the overall response of hypocretin neurons to cholinergic inputs, we tested the effect of ACh in the absence of atropine to engage both nAChRs and mAChRs. ACh induced depolarization and increased firing rate in $57 \%$ (8 out of 14) of hypocretin neurons (Fig. 1G), a significant increase compared to the presence of atropine $\left(\chi^{2}\right.$ test, $\left.p=0.0040\right)$. The remaining cells showed no effect (1 out of 14 cells) or responded to ACh with decreased firing (5 out of 14 cells).

\section{Postsynaptic nAChR currents can be induced in one third of hypocretin neurons}

Although mRNAs encoding nAChR subunits are expressed in lateral hypothalamus (Clarke et al., 1985; Wada et al., 1989) where Hcrt+ neurons reside, it is not yet clear on which cell types and in what subcellular structure nAChRs are functional, and whether Hcrt+ neurons express nAChRs. To dissect the mechanisms underlying nicotinic stimulation of Hcrt+ neurons, we evaluated postsynaptic nAChRs on Hcrt+ neurons selectively by using synaptic blockers to rule out contributions from glutamate- and GABA-activated currents. We recorded from Hcrt + neurons in voltage clamp mode in the presence of TTX $(0.5 \mu \mathrm{M})$, PTX $(100 \mu \mathrm{M}), \mathrm{CNQX}(10 \mu \mathrm{M}), \mathrm{AP}-5$ $(30 \mu \mathrm{M})$, and atropine $(4 \mu \mathrm{M})$, while puffing $1 \mathrm{mM}$ ACh onto the cell body of the recorded cell. A brief puff of $\mathrm{ACh}$ evoked an inward current in about one-third of Hcrt+ neurons (32 out of 92 cells). The peak amplitudes of the inward currents ranged from -10 to $-850 \mathrm{pA}$, with an average size of $-71.1 \pm 30.9 \mathrm{pA}(n=32)$. We also tested the nAChR agonist nicotine $(100 \mu \mathrm{M})$. A nicotine puff produced a response similar to that induced by ACh in $\mathrm{Hcrt}+$ neurons. Inward currents were recorded in 9 out of 29 cells, ranging from -10 to $-1500 \mathrm{pA}$, with an average size of $-413 \pm 178 \mathrm{pA}(n=9$; Fig. 3$)$. We also wished to determine whether the small currents might be sufficient to alter the function of the Hcrt+ neurons. Injection of a small inward current $(-10 \mathrm{pA})$ markedly increased the spontaneous action potential firing rate to $324 \% \pm 101 \%$ (Student's $t$ test, $p=1.0 \mathrm{E}-5, n=3$ ) of the baseline level (Fig. 1B4), suggesting that nicotinic currents are likely to have a significant effect on the output of these cells. nAChRs are known to be easily desensitized by agonists (Giniatullin et al., 2005). Consistent with these observations, we observed that postsynaptic nAChR-mediated currents on Hcrt+ neurons were desensitized following 5 $\mathrm{s}$ exposure to $1 \mathrm{mM}$ ACh or $100 \mu \mathrm{M}$ nicotine. Previous studies have shown that most $\mathrm{nAChR}$ subtypes, including $\alpha 4 \beta 2, \alpha 3 \beta 4$ and $\alpha 7$, recover from the desensitization induced by brief $(1-5 \mathrm{~s})$ exposure to $1 \mathrm{mM} \mathrm{ACh}$ in $60 \mathrm{~s}$ or less (Reitstetter et al., 1999; Meyer et al., 2001; Paradiso and Steinbach, 2003; McCormack et al., 2010). While the majority of currents did not recover rapidly following ACh stimulation, we observed a rare subset of Hcrt + neurons ( 3 out of 121 cells) that responded to 

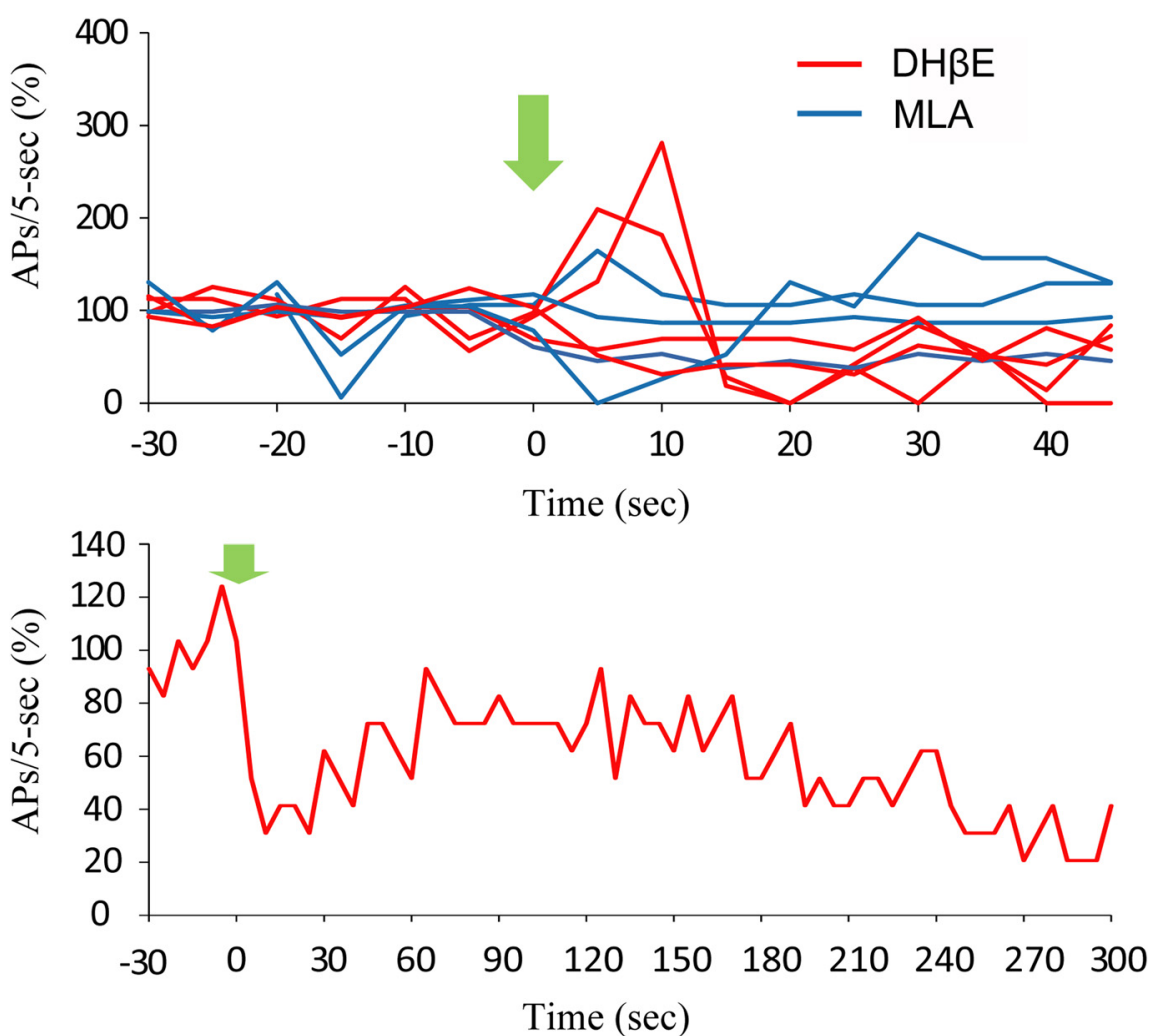

Figure 2 The effects of $\alpha 4 \beta 2$ receptor antagonist, $\mathrm{DH} \beta \mathrm{E}$, and $\alpha 7 *$ receptor antagonist, MLA, on the action potential firing of Hcrt+ neurons. Top, Change of firing rate (action potentials $/ 5 \mathrm{~s}$ ) before and after bath application of $\mathrm{DH} \beta \mathrm{E}$ (red) and MLA (blue). Bottom, $\mathrm{A}$ representative cell reduced in firing rate upon bath application of $\mathrm{DH} \beta \mathrm{E}$, and partially recovered over time.

repeated ACh or nicotine puffs every $60 \mathrm{~s}$ (Fig. 3A2), which happened only when the current size was greater than $500 \mathrm{pA}$.

\section{Acetylcholine and nicotine decrease the frequency of mEPSCs in hypocretin neurons}

Next, we tested whether nAChRs are expressed in presynaptic glutamatergic terminals that impinge onto Hcrt+ neurons, and what physiological changes might occur to synaptic transmission following presynaptic receptor stimulation. To do this, we applied TTX, PTX, and atropine in the bath and recorded spontaneous mEPSCs from the Hcrt + neurons. A brief puff of ACh above the tissue surface next to the Hcrt+ neuron reliably decreased mEPSC occurrence for $\sim 1 \mathrm{~min}$, followed by full recovery (Fig $4 A, B$ ). The average instantaneous frequencies of mEPSCs at baseline, upon ACh application, and after washout were $3.76 \pm 0.19 \mathrm{~Hz}, 0.64 \pm 0.12 \mathrm{~Hz}$, and 3.48 $\pm 0.31 \mathrm{~Hz}$, respectively. The average peak amplitudes of mEPSCs at baseline, upon ACh application, and washout were $26.4 \pm 0.3 \mathrm{pA}, 21.8 \pm 0.8 \mathrm{pA}$, and $30.0 \pm 0.5 \mathrm{pA}$, respectively. Analysis shows that phasic stimulation of preterminal nAChRs significantly reduced vesicle release probability by $83.0 \%(p=2.06 \mathrm{E}-39)$. The average peak size of mEPSCs was also slightly reduced by $17.4 \%$ ( $p=$ 1.88E-7; Fig. 4C,D).

Nicotine is a strong exogenous agonist of nAChRs, and also a prevalent drug of addiction. During cigarette smok- ing, nicotine concentration increases rapidly in the brain (Berridge et al., 2010; Rose et al., 2010). To mimic this fast onset of brain nicotine concentration, we pipetted $5 \times$ nicotine solutions into the recording chamber within $5 \mathrm{~s}$, to a final concentration of $1 \mu \mathrm{M}$ (Henningfield et al., 1993). In 4 out of 11 tested cells, the mEPSC frequency was immediately depressed from $5.37 \pm 0.59 \mathrm{~Hz}$ to $2.02 \pm$ $0.23 \mathrm{~Hz}$ (Fig. $5 A-C$ ). In an additional four cells, the immediate effect of nicotine was not significant, with frequency changed from $2.97 \pm 0.40 \mathrm{~Hz}$ to $3.39 \pm 0.52 \mathrm{~Hz}$ $(p=0.527$; Fig. $5 D-F, T-1)$, but following this initial $1-2$ min period, suppression of mEPSC frequency $(0.96 \pm$ $0.17 \mathrm{~Hz}, p=6.8 \mathrm{E}-6$ ) was observed for $1-2 \mathrm{~min}$ (Fig. $5 D-F, T-2)$. Finally, there were three cells with no obvious response to nicotine exposure.

\section{Antagonists of $n A C h R s$ mimic the effect of agonist application on $\mathrm{mEPSC}$ frequency}

Under physiological conditions, activation of nAChRs induces excitatory inputs by evoking inward currents. The suppressive effect on mEPSCs might therefore be due to desensitization of nAChRs. To test this possibility, we applied mecamylamine (MEC), a nonselective antagonist of nAChRs. The application of MEC alone caused a substantial suppression of mEPSCs (Fig. 6), with instantaneous frequency decreased to $37.6 \%$ (from $6.49 \pm 0.32$ $\mathrm{Hz}$ to $2.44 \pm 0.24 \mathrm{~Hz}, p=1.82 \mathrm{E}-23)$, and amplitude decreased to $80.7 \%$ (from $31.6 \pm 0.4 \mathrm{pA}$ to $25.5 \pm 0.4 \mathrm{pA}$, 

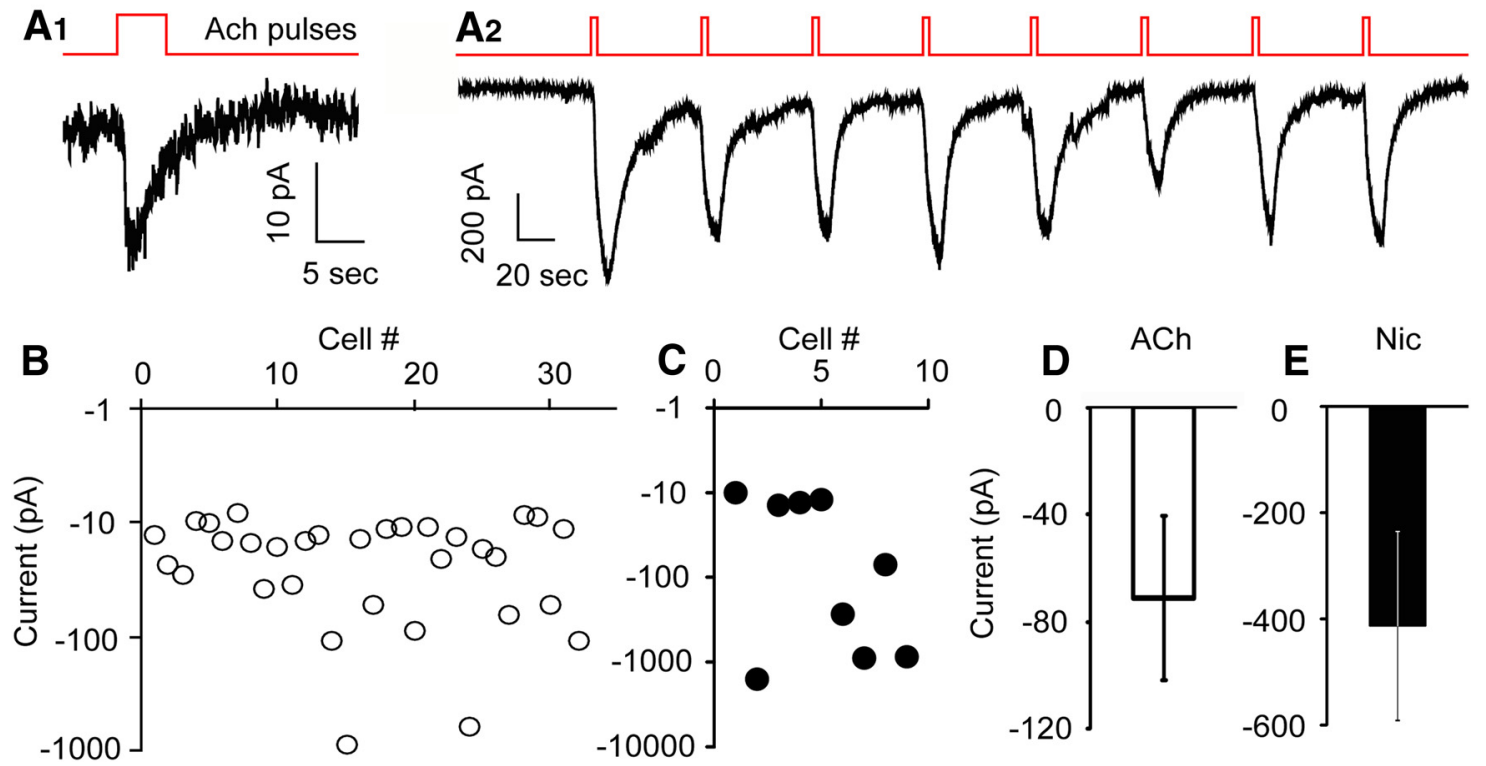

Figure 3 Nicotinic stimulation induced variable inward currents in a third of Hcrt+ neurons. $\boldsymbol{A}_{1}, A$ small, desensitizing current evoked by ACh (1 mM) puff, in the presence of atropine $(4 \mu \mathrm{M})$. $\boldsymbol{A}_{2}$, Large, repetitive currents evoked by ACh (1 mM) puff every $60 \mathrm{~s}$. $\boldsymbol{B}$, In 32 out of $92 \mathrm{Hcrt}+$ neurons, an ACh $(1 \mathrm{mM})$ puff evoked inward currents of variable size. $\boldsymbol{C}$, In 9 out of $29 \mathrm{Hcrt}+$ neurons, a nicotine $(\mathrm{Nic} ; 100 \mu \mathrm{M})$ puff evoked inward currents of variable size. $\boldsymbol{D}, \boldsymbol{E}$, Mean sizes of currents evoked by puffing ACh (1 mM; $\boldsymbol{B}$ ) or nicotine $(100 \mu \mathrm{M} ; \boldsymbol{C})$, respectively, onto Hcrt+ neurons.

$p=1.47 \mathrm{E}-22)$ of baseline values. Furthermore, both the heteromeric (predominantly $\alpha 4 \beta 2$ ) nAChR antagonist $\mathrm{DH} \beta \mathrm{E}(10 \mu \mathrm{M})$ and the homomeric, $\alpha 7 \mathrm{nAChR}$ antagonist MLA (10 nM) partially reduced event frequency to $62.5 \%$ (from $6.45 \pm 0.46 \mathrm{~Hz}$ to $4.04 \pm 0.28 \mathrm{~Hz}, p=1.09 \mathrm{E}-5$ ) and $76.8 \%$ (from $9.88 \pm 0.57 \mathrm{~Hz}$ to $7.58 \pm 0.47 \mathrm{~Hz}, p=$ 1.94E-3) of baseline values. The mEPSC peak amplitude was also reduced to $87.4 \%$ (from $21.4 \pm 0.5 \mathrm{pA}$ to $18.7 \pm$ $0.4 \mathrm{pA}, p=5.74 \mathrm{E}-5$ ) and $81.5 \%$ (from $24.3 \pm 0.6 \mathrm{pA}$ to $19.8 \pm 0.4 \mathrm{pA}, p=8.18 \mathrm{E}-10)$ of their baseline levels, respectively (Fig. $6 D-G$ ), consistent with what was observed following ACh or nicotine application (Figs. 4, 5).

\section{Blockade of $\mathrm{Ca}^{2+}$ internal stores occludes the effect of ACh on mEPSC frequency}

Synaptic vesicle release is a calcium-dependent process (Neher and Sakaba, 2008; Südhof, 2012). Spontaneous vesicle release, unlike action potential-evoked events, is independent of extracellular calcium and voltage-gated calcium channel opening, but is instead driven largely by calcium release from internal stores (Llano et al., 2000; Emptage et al., 2001; Han et al., 2001). To determine whether $\mathrm{nAChR}$ stimulation affects calcium release from internal stores, we applied dantrolene (50 $\mu \mathrm{M})$ and $(-)$ Xestospongin $\mathrm{C}(\mathrm{XeC})(5 \mu \mathrm{M})$ to block ryanodine and $\mathrm{IP}_{3}$ receptors in the endoplasmic reticulum membrane (Dickinson et al., 2008). Following 30 min incubation with dantrolene and $\mathrm{XeC}$, the mEPSCs instantaneous frequency was reduced to $50.7 \%$ of its baseline value (4.90 \pm 0.48 $\mathrm{Hz}$ to $2.48 \pm 0.38 \mathrm{~Hz}, p=7.12 \mathrm{E}-4$; Fig. 7), in agreement with previous reports that approximately half of spontaneous vesicle release is due to internal calcium stores (Emptage et al., 2001). The peak amplitude was reduced to $80.6 \%(21.1 \pm 0.7 \mathrm{pA}$ to $17.0 \pm 0.5 \mathrm{pA}, p=5.18 \mathrm{E}-5)$. In the continued presence of dantrolene and $\mathrm{XeC}$, we pressure applied ACh onto Hcrt+ neurons and found that both amplitude (from $17.0 \pm 0.5 \mathrm{pA}$ to $18.0 \pm 0.5 \mathrm{pA}, p=$ 0.664 ) and frequency of mEPSCs (from $2.48 \pm 0.38 \mathrm{~Hz}$ to $2.25 \pm 0.37 \mathrm{~Hz}, p=0.151$ ) remained unchanged (Fig. $7 C, D)$. Thus, blockade of calcium release from internal store occluded the effect of subsequent nAChR stimulation.

\section{Discussion}

Hypocretin/orexin neurons are involved in multiple behaviors, including those related to arousal and addiction (Mahler et al., 2012; de Lecea and Huerta, 2014). Understanding how the electrical activity of Hcrt + neurons is modulated by endogenous neurotransmitters and exogenous drugs such as nicotine is critical for understanding the role of these cells in complex behaviors, including nicotine dependence. As a candidate modulator, nAChRs have been shown to be expressed in hypothalamus. Stimulation of these receptors can activate Hcrt+ neurons (Pasumarthi et al., 2006; Pasumarthi and Fadel, 2008; Morgan et al., 2013); however, the underlying mechanisms by which $\mathrm{nAChRs}$ modulate the activity of Hcrt+ neurons are still unclear.

In the current study, we used pressure application to mimic phasic ACh neurotransmission (Alexander et al., 2009) and investigated the effects of ACh and nicotine acting through presynatpic and postsynaptic nAChRs on glutamatergic transmission and postsynaptic electrical activity in Hcrt+ neurons. We found that nAChRs are expressed postsynaptically in around one-third of Hcrt+ neurons, as well as presynaptically on glutamatergic axon 


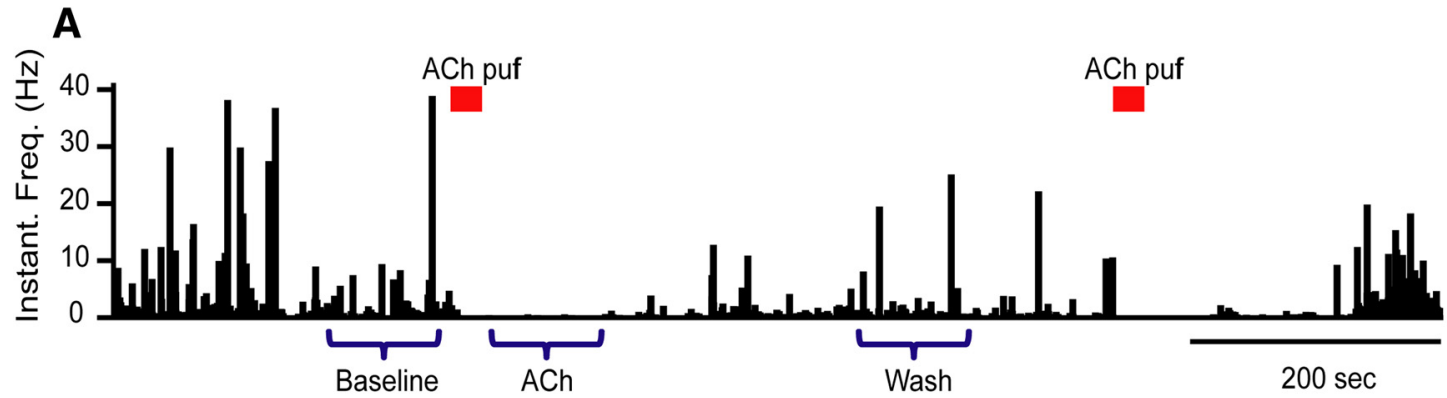

Baseline

B1

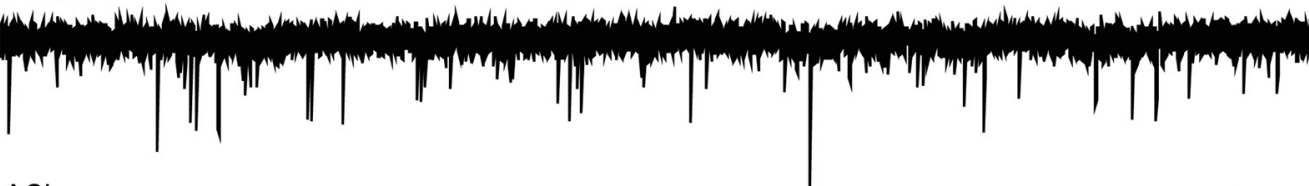

B2

$\mathrm{ACh}$

B3

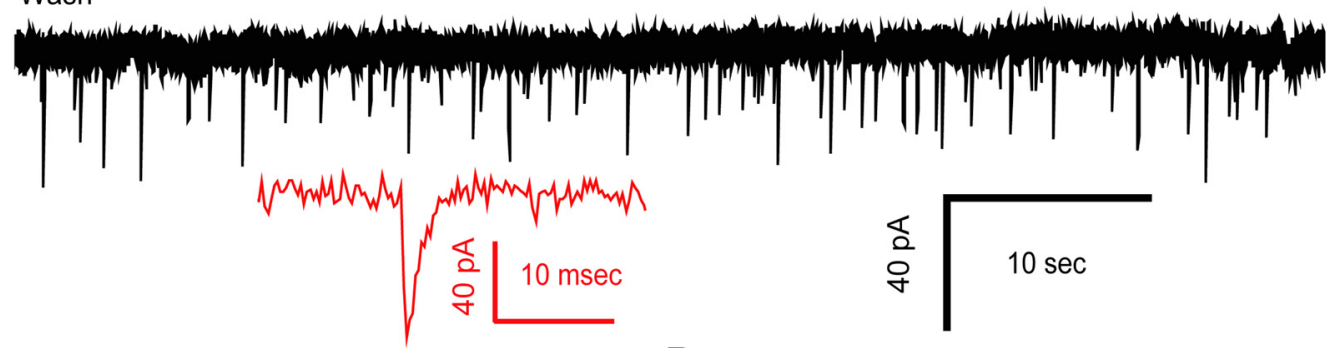

C

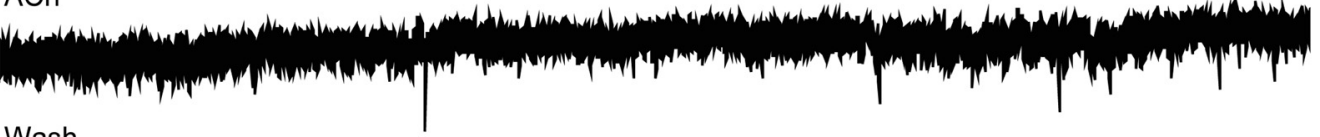

Wash
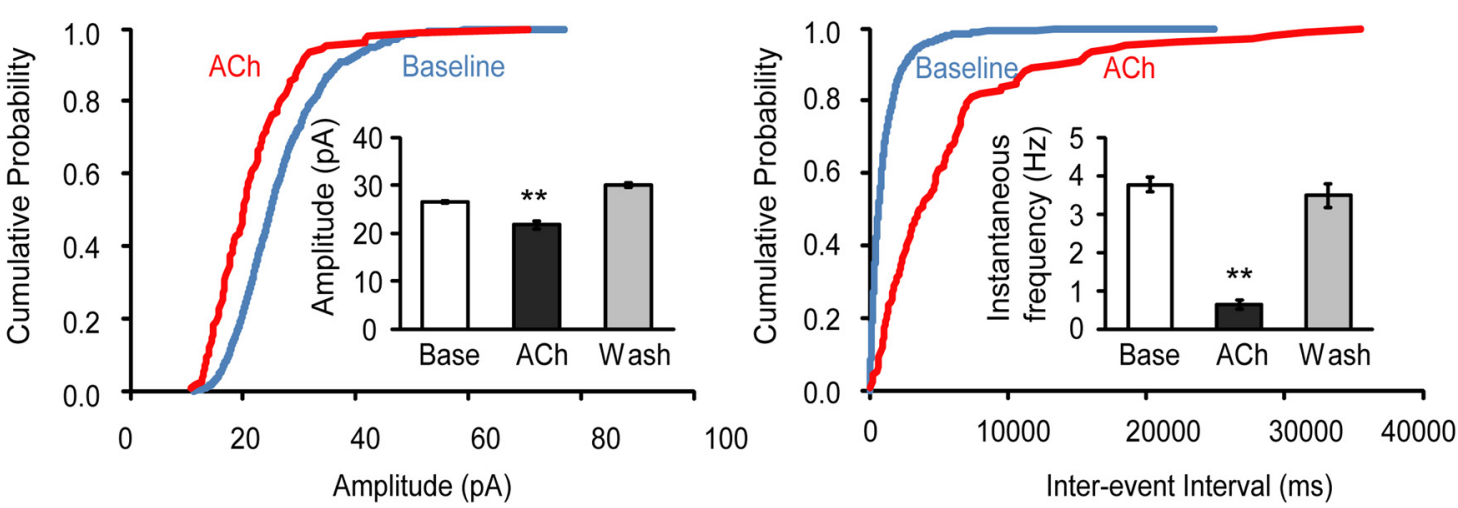

Figure 4 ACh suppresses glutamatergic spontaneous mEPSCs onto Hcrt+ neurons in the presence of atropine. A, Histograms of mEPSC instantaneous frequency show the time course of the effect of ACh on glutamatergic mEPSCs from synapses impinging onto Hcrt+ neurons. Bars above the graph indicate the time point of the ACh (1 mM) puff. The original recordings indicated by "Baseline", "Ach", and "Wash" are displayed in $\boldsymbol{B}_{\mathbf{1}}, \boldsymbol{B}_{\mathbf{2}}$, and $\boldsymbol{B}_{\mathbf{3}}$, respectively. Inset shows the full trace of an example mEPSC event. $\boldsymbol{C}$, Cumulative probability plot of the mEPSC amplitude at baseline and upon ACh application from six cells. Inset shows the mean value of the mEPSC amplitude at three time periods: baseline, under the influence of ACh, and washout. $* * p<0.01$. D, Interevent intervals of mEPSCs at baseline and upon ACh application from six cells (same cells as in $\boldsymbol{C}$ ). Inset shows the mean of instantaneous frequency of the mEPSC at three periods of time: baseline, under the influence of ACh, and after washout.

terminals to Hcrt + neurons. Stimulation of presynaptic or postsynaptic nAChRs produced opposing effects on electrical activity in Hcrt+ neurons, however. Stimulation of postsynaptic nAChRs evoked an inward current in a fraction (approximately one-third) of Hcrt+ neurons (Fig. 3). This current, which was as small as $10 \mathrm{pA}$, ranging to more than $1000 \mathrm{pA}$, depolarized the membrane potential and increased spontaneous firing of Hcrt + neurons (Fig. 1). In contrast, stimulation of presynaptic nAChRs reliably decreased the frequency of mEPSCs in Hcrt+ neurons (Fig. 4), indicating the efficacy of glutamatergic transmission was decreased. At a concentration consistent with 


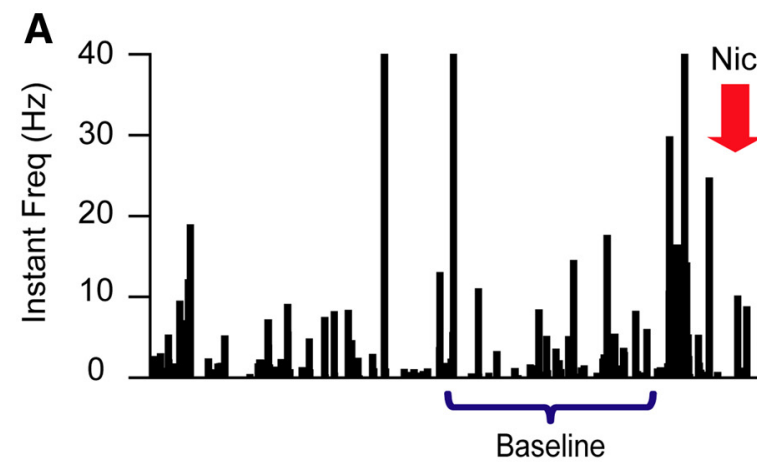

B

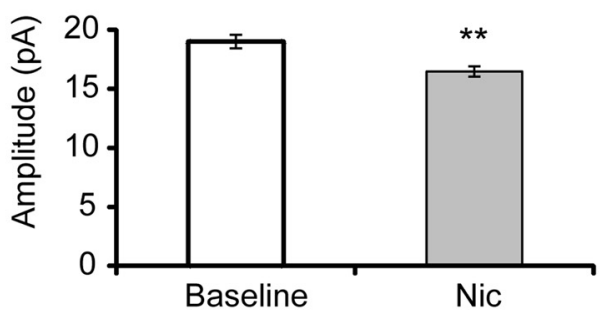

\section{D}
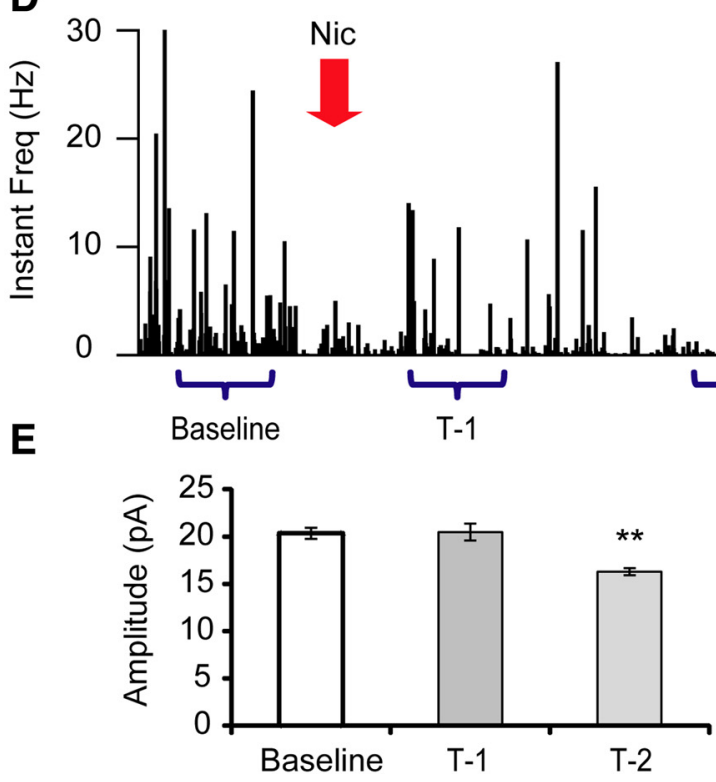

$100 \mathrm{sec}$

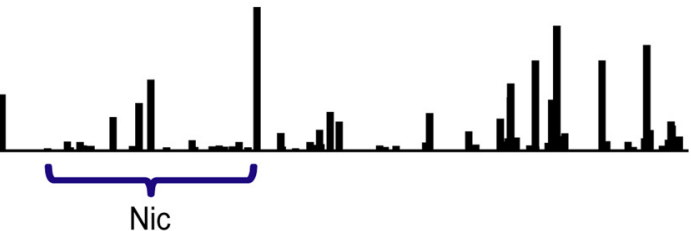

C

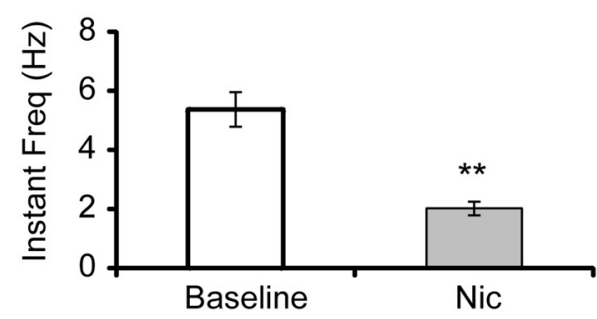

Figure 5 Effects of nicotine exposure on glutamatergic mEPSCs onto Hcrt+ neurons. A, Histograms of mEPSC instantaneous frequency showing the effect of nicotine (Nic) exposure $(100 \mu \mathrm{M})$ on mEPSCs onto Hcrt+ neurons. The arrow indicates the time of nicotine application. Depending on the response pattern, two periods of time (baseline and Nic) were used for analysis. $\boldsymbol{B}, \boldsymbol{C}$, Mean value of amplitude $(\boldsymbol{B})$ and instantaneous frequency $(\boldsymbol{C})$ at baseline and under the influence of nicotine. $n=4$ of 11 cells. $* * p<0.01$. $\boldsymbol{D}$, Histograms show another representative response to nicotine $(1 \mu \mathrm{M})$ on mEPSCs onto an Hcrt+ neuron. Three periods of time (baseline, T-1, and T-2) were used for analysis. $\boldsymbol{E}, \boldsymbol{F}$, Mean value of amplitude $(\boldsymbol{E})$ and instantaneous frequency $(\boldsymbol{F})$ of mEPSCs during baseline recording and at two periods after nicotine exposure. $n=4$ of 11 cells.

cigarette smoking, nicotine suppressed mEPSCs in a majority ( $70 \%)$ of Hcrt+ neurons (Fig. 5). The nonselective nAChR antagonist mecamylamine depressed mEPSC frequency to a similar extent (Fig. 6), suggesting that the suppressing effect of ACh on mEPSCs was likely mediated by desensitization of presynaptic nAChRs, and that an endogenous, tonic activation of presynaptic nAChRs might be required for maintaining normal, functional mEPSC frequency. It should be noted that inhibitory inputs impinging on hypocretin neurons are also likely to express nAChRs, and therefore could also be regulated by ACh; however, inhibitory inputs were excluded using picrotoxin in this study.

To explore the mechanism underlying the AChmediated decrease in mEPSC frequency, we determined the role of calcium release from internal stores (Llano et al., 2000; Cheng and Lederer, 2008), since intracellular calcium stores are thought to be required for spontaneous vesicle release (Emptage et al., 2001). In the presence of the ryanodine receptor blocker dantrolene and the IP3 
A

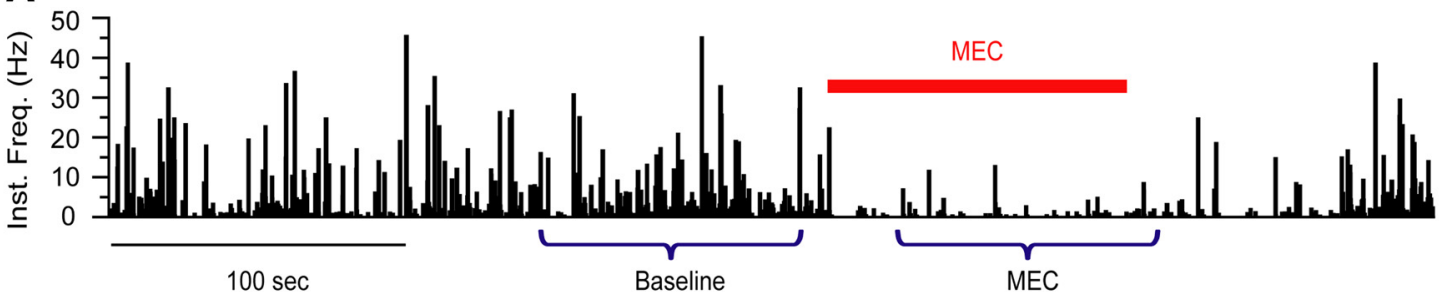

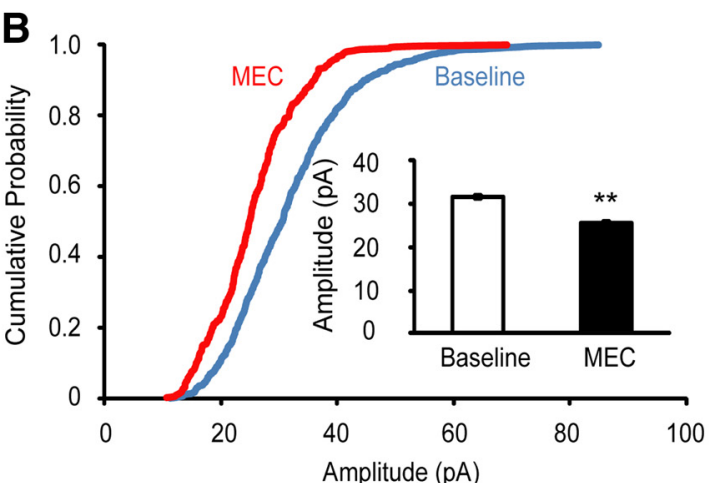

D

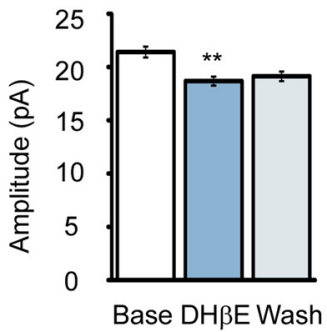

E

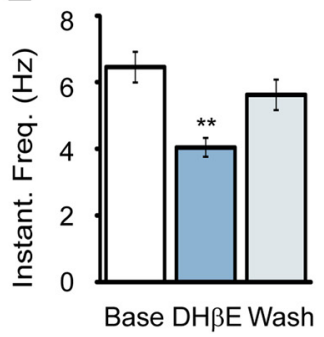

C

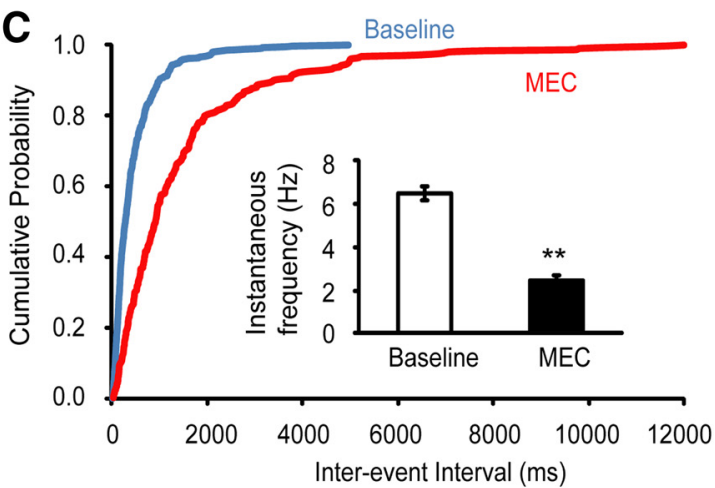

F

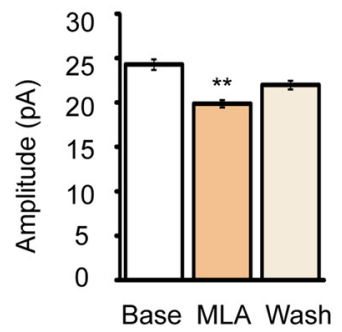

G

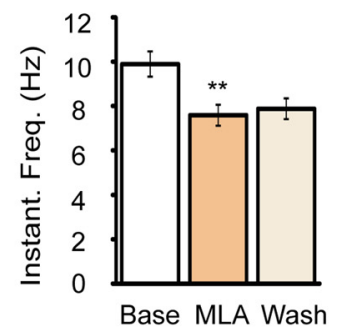

Figure 6 Nicotinic AChR antagonists suppressed glutamatergic mEPSCs onto Hcrt+ neurons. A, Mecamylamine, a nonselective $\mathrm{nAChR}$ antagonist, strongly suppressed mEPSCs onto Hcrt+ neurons. The bar above the graph indicates the duration of MEC (10 $\mu \mathrm{M})$ exposure. Miniature EPSCs from two periods of time (Baseline and MEC) were used for analysis. B, Cumulative probability plot of the mEPSC amplitude at baseline and during MEC exposure was made from the recordings of four cells. Inset shows the mean values of the mEPSC amplitude at baseline and following MEC exposure. $* * p<0.01$. $\boldsymbol{C}$, Interevent intervals of mEPSCs at baseline and upon MEC application from four cells (same cells as in $\mathbf{C}$ ). Inset shows the mean instantaneous frequency of the mEPSCs at baseline and following MEC exposure. $\boldsymbol{D}, \boldsymbol{E}, \mathrm{DH} \beta \mathrm{E}$, an antagonist of heteromeric nAChRs (particularly $\alpha 4 \beta 2 \mathrm{nAChRs),} \mathrm{moderately}$ suppressed the amplitude $(\boldsymbol{D})$ and instantaneous frequency $(\boldsymbol{E})$ of mEPSCs onto Hcrt+ neurons. $n=7$ cells. $\boldsymbol{F}$, $\boldsymbol{G}$, MLA, a relatively selective $\alpha 7$ nAChR antagonist, partially suppressed mEPSC amplitude $(\boldsymbol{F})$ and instantaneous frequency $(\boldsymbol{G}) . n=8$ cells.

receptor blocker XeC (Dickinson et al., 2008), mEPSC frequencies in Hcrt+ neurons were significantly decreased. The application of ACh did not further decrease mEPSC frequencies (Fig. 7), indicating that phasic nAChR stimulation (i.e., endogenous $A C h$ release from cholinergic synapses) could desensitize tonically active nAChRs and thereby decrease calcium release from internal stores, preventing $\mathrm{Ca}^{2+}$-dependent spontaneous vesicle release. Previous studies have shown that nicotine can transiently facilitate neurotransmitter release, and one study in mouse vas deferens indicated that this is mediated by calcium-induced calcium release from a ryanodine-sensitive calcium store in nerve terminals (Brain et al., 2001). Here, we propose that in the mouse central nervous system, at least in glutamatergic synapses impinging onto Hcrt+ neurons, this mechanism is also present. Tonic activation of presynaptic nAChRs contributes to spontaneous vesicle release via transient opening of ryanodine receptors and/or IP3 receptors in local internal calcium stores. Levels of nicotine delivered through cigarette smoking are sufficient to interfere with this function, and this mechanism could therefore contribute to behaviors related to nicotine dependence.

The opening of nAChRs channels leads to the influx of cations, and generally excites the postsynaptic neurons (Léna and Changeux, 1997; Zhou et al., 2001; Mansvelder et al., 2002; Sharma et al., 2008; Huang et al., 2011). In the current study, this direct depolarizing effect of nAChR activation was also demonstrated for mouse Hcrt+ neurons, likely leading to hypocretin release in downstream neuronal circuits. The pharmacological experiments shown here, along with previous studies (Pasumarthi et al., 2006; Pasumarthi and Fadel, 2008; Morgan et al., 2013), suggest that $\alpha 4 \beta 2 * \mathrm{nAChRs}$ are most critical for postsynaptic responses to ACh and nicotine in Hcrt+ neurons; postsynaptic $\alpha 7 \mathrm{nAChRs}$ also contribute to 


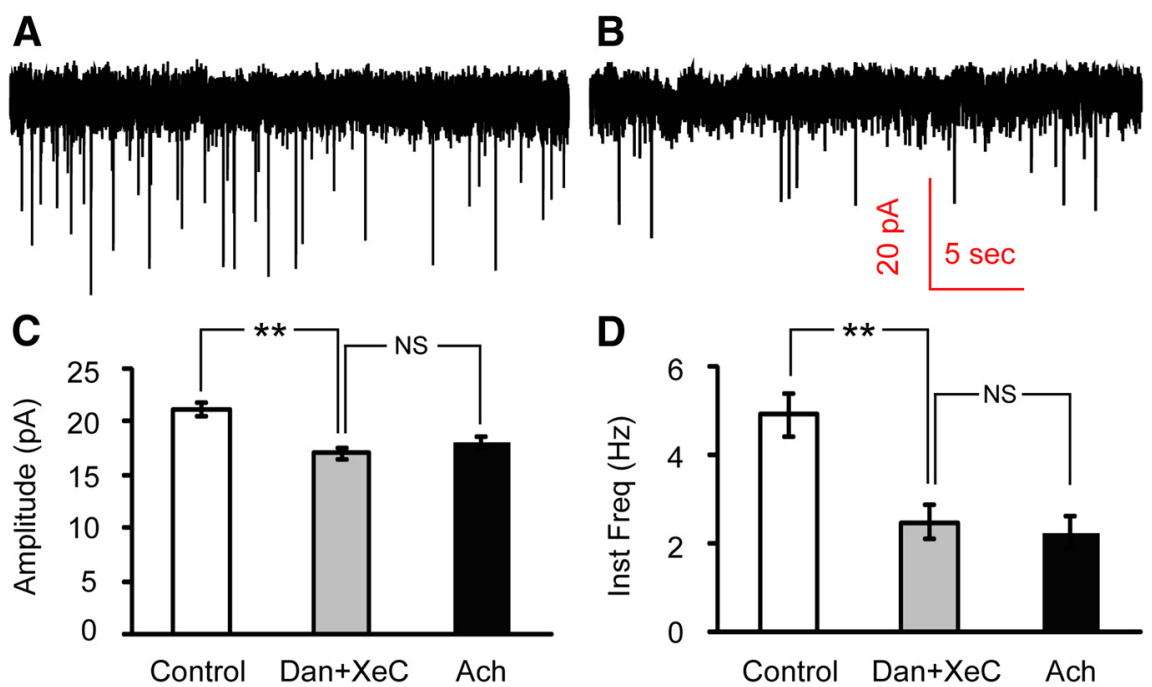

Figure 7 Inhibiting calcium release from internal stores occludes the effect of ACh on mEPSCs onto Hcrt+ neurons. $\boldsymbol{A}$, $\boldsymbol{B}$, mEPSCs recorded at baseline $(\boldsymbol{A})$ and after $30 \mathrm{~min}$ incubation with the ryanodine receptor antagonist dantrolene (50 $\mu \mathrm{M})$ and the IP3 receptor antagonist (-)-Xestospongin $C(5 \mu \mathrm{M} ; \boldsymbol{B})$. C , D. Mean values of amplitude $(\boldsymbol{C})$ and instantaneous frequency $(\boldsymbol{D})$ of $\mathrm{mEPSCs}$ at baseline, after 30 min incubation with dantrolene (Dan) and $\mathrm{XeC}$ and upon subsequent ACh puff in the continued presence of dantrolene and XeC. $n=3$ cells. Both amplitude and instantaneous frequency were significantly decreased by dantrolene + XeC, but there was no significant difference between mEPSC recordings in the presence of dantrolene and $\mathrm{XeC}$ and upon subsequent $\mathrm{ACh}$ puffs in the continued presence of these inhibitors. $* * p<0.01$; NS, not significant $(p>0.05)$.

Hcrt+ nicotinic responses, but are less prominent. Blockade of $\alpha 4 \beta 2 *$ receptors by $\mathrm{DH} \beta \mathrm{E}$ not only decreases mEPSCs by disrupting presynaptic nicotinic signaling, but also prevents the activation of postsynaptic nicotinic receptors, and therefore affects spontaneous firing of Hcrt+ neurons. In contrast, the role of presynaptic nAChRs has not been reported previously. In our experimental para- digm, either pressure application of $\mathrm{ACh}(1 \mathrm{mM})$ onto the soma and the proximal processes or bath application of nicotine $(1 \mu \mathrm{M})$ suppressed the spontaneous mEPSC frequency in Hcrt+ neurons, which is consistent with effects reported in the arcuate nucleus of the hypothalamus (Huang et al., 2011). We also observed a consistent, though modest, reduction in mEPSC size that always
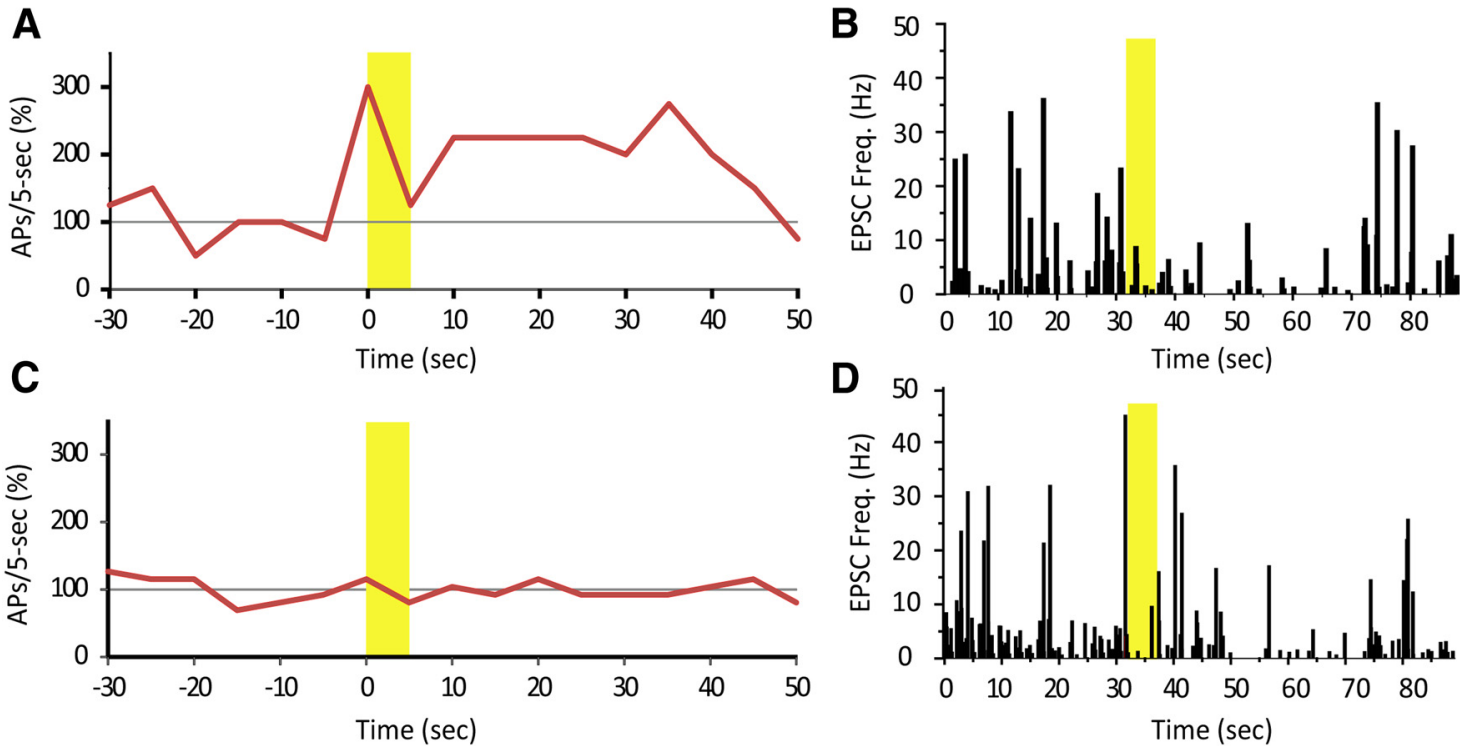

Figure $8 \mathrm{ACh}$ increased action potential (AP) firing or had no effect. In the same cells, however, ACh decreased mEPSC occurrence despite of its effect on action potential firing. $\boldsymbol{A}, \mathrm{A}$ Hcrt + cell increased action potential firing rate in response to ACh, in presence of atropine. $\boldsymbol{B}$, In the same cell, a puff of ACh decreased mEPSC frequency. Yellow bars indicate the time duration of ACh application. $\boldsymbol{C}$, Another Hcrt+ cell did not change action potential firing rate upon ACh puff. $\boldsymbol{D}$, In the same cell, a puff of ACh decreased mEPSC frequency. 
accompanied the reduction in mEPSC frequency (Figs. $4-7$ ). This could be due to effects of nicotinic signaling on activity of postsynaptic ionotropic glutamate receptors, in particular AMPA receptors. It is also possible that large presynaptic vesicles (Wojcik et al., 2004) or proximal synapses (which produce mEPSCs with larger amplitudes than distal ones; Bekkers and Stevens, 1996) are more significantly recruited by nicotinic signaling. Interestingly, the nicotinic antagonist, MEC, had a similar effect as ACh and nicotine on mEPSC frequency and amplitude (Figs. $4-6)$. Partial blockade of $\alpha 4 \beta 2$ or $\alpha 7 \mathrm{nAChRs}$ by more selective antagonists also reduced mEPSC frequency, indicating that both heteromeric and homomeric nAChRs in brain are present in presynaptic glutamatergic terminals impinging on Hcrt+ neurons. These results suggest that both ACh and nicotine likely desensitize nAChRs and interrupt glutamatergic transmission onto Hcrt+ neurons, further suggesting that tonic activation of presynaptic nAChRs might be necessary for the normal function of neurotransmission in glutamatergic synapses impinging onto these neurons (Brain et al., 2001). Phasic cholinergic release may temporarily interrupt or reduce this tonic glutamatergic transmission. It is also possible that stimulation of postsynaptic nAChRs depolarizes membrane potential and releases calcium from internal stores, facilitating release of retrograde signaling molecules, such as endocannabinoids (Huang et al., 2007) or dynorphin (Li and van den Pol, 2006), that result in negative feedback. These paradoxical presynaptic and postsynaptic effects of ACh may improve the signal-tonoise ratio of selective $\mathrm{Hcrt}+$ firing during phasic release, as might occur during exposure to behaviorally relevant stimuli (Dalley et al., 2001; Parikh et al., 2007), or in response to nicotine during smoking or behaviors relevant to drug reinforcement (Hollander et al., 2008). In particular, phasic ACh release would be expected to stimulate the firing of the approximately one-third of Hcrt+ neurons expressing nAChRs, while also reducing activity in the remaining two-thirds of Hcrt+ neurons by blocking synaptic excitatory events supported by tonic activation of presynaptic nAChRs (Fig. 8).

In conclusion, these results suggest that ACh modulates the Hcrt system through a multifaceted, nAChRmediated mechanism, which is complementary to the effects of muscarinic modulation of these neurons (Sakurai et al., 2005). More importantly, nAChR-mediated effects of ACh may enhance the output of a selective group of Hcrt+ neurons expressing nAChRs, and distinguish this subset from the overall hypocretin network.

\section{References}

Alexander KS, Brooks JM, Sarter M, Bruno JP (2009) Disruption of mesolimbic regulation of prefrontal cholinergic transmission in an animal model of schizophrenia and normalization by chronic clozapine treatment. Neuropsychopharmacology 34:27102720.CrossRef

Avissar S, Egozi Y, Sokolovsky M (1981) Studies on muscarinic receptors in mouse and rat hypothalamus: a comparison of sex and cyclical differences. Neuroendocrinology 32:295-302. Medline

Bayer L, Eggermann E, Saint-Mleux B, Machard D, Jones BE, Mühlethaler M, Serafin M (2002) Selective action of orexin (hypocretin) on nonspecific thalamocortical projection neurons. J Neurosci 22:7835-7839. Medline
Bekkers JM, Stevens CF (1996) Cable properties of cultured hippocampal neurons determined from sucrose-evoked miniature EPSCs. J Neurophysiol 75:1250-1255. Medline

Berridge MS, Apana SM, Nagano KK, Berridge CE, Leisure GP, Boswell MV (2010) Smoking produces rapid rise of [11C]nicotine in human brain. Psychopharmacology (Berl) 209:383-394. CrossRef Medline

Blouin AM, Fried I, Wilson CL, Staba RJ, Behnke EJ, Lam HA, Maidment NT, Karlsson KA, Lapierre JL, Siegel JM (2013) Human hypocretin and melanin-concentrating hormone levels are linked to emotion and social interaction. Nat Commun 4:1547[PMC] [CrossRef] [Medline]

Boutrel B, Kenny PJ, Specio SE, Martin-Fardon R, Markou A, Koob GF, de Lecea L (2005) Role for hypocretin in mediating stressinduced reinstatement of cocaine-seeking behavior. Proc Natl Acad Sci U S A 102:19168-19173. CrossRef Medline

Boutrel B, Cannella N, de Lecea L (2010) The role of hypocretin in driving arousal and goal-oriented behaviors. Brain Res 1314:103111. CrossRef Medline

Brain KL, Trout SJ, Jackson VM, Dass N, Cunnane TC (2001) Nicotine induces calcium spikes in single nerve terminal varicosities: a role for intracellular calcium stores. Neuroscience 106:395-403. Medline

Cheng H, Lederer WJ (2008) Calcium sparks. Physiol Rev 88:14911545. CrossRef Medline

Clarke PB, Schwartz RD, Paul SM, Pert CB, Pert A (1985) Nicotinic binding in rat brain: autoradiographic comparison of $[3 \mathrm{H}]$ acetylcholine, [3H]nicotine, and [125I]-alpha-bungarotoxin. J Neurosci 5:1307-1315. Medline

Dalley JW, McGaughy J, O'Connell MT, Cardinal RN, Levita L, Robbins TW (2001) Distinct changes in cortical acetylcholine and noradrenaline efflux during contingent and noncontingent performance of a visual attentional task. J Neurosci 21:4908-4914. Medline

de Lecea L, Huerta R (2014) Hypocretin (orexin) regulation of sleepto-wake transitions. Front Pharmacol 5:16[PMC] [CrossRef] [Medline]

de Lecea L, Kilduff TS, Peyron C, Gao X, Foye PE, Danielson PE, Fukuhara C, Battenberg EL, Gautvik VT, Bartlett FS 2nd, Frankel WN, van den Pol AN, Bloom FE, Gautvik KM, Sutcliffe JG (1998) The hypocretins: hypothalamus-specific peptides with neuroexcitatory activity. Proc Natl Acad Sci U S A 95:322-327.CrossRef

Dickinson JA, Kew JN, Wonnacott S (2008) Presynaptic alpha 7- and beta 2-containing nicotinic acetylcholine receptors modulate excitatory amino acid release from rat prefrontal cortex nerve terminals via distinct cellular mechanisms. Mol Pharmacol 74:348-359. CrossRef Medline

Emptage NJ, Reid CA, Fine A (2001) Calcium stores in hippocampal synaptic boutons mediate short-term plasticity, store-operated $\mathrm{Ca} 2+$ entry, and spontaneous transmitter release. Neuron 29:197208. Medline

Gao XB, Horvath T (2014) Function and dysfunction of hypocretin/ orexin: an energetics point of view. Annu Rev Neurosci 37:101116. CrossRef Medline

Giniatullin R, Nistri A, Yakel JL (2005) Desensitization of nicotinic ACh receptors: shaping cholinergic signaling. Trends Neurosci 28:371378. CrossRef Medline

Gioanni Y, Rougeot C, Clarke PB, Lepousé C, Thierry AM, Vidal C (1999) Nicotinic receptors in the rat prefrontal cortex: increase in glutamate release and facilitation of mediodorsal thalamo-cortical transmission. Eur J Neurosci 11:18-30. Medline

Girault EM, Yi CX, Fliers E, Kalsbeek A (2012) Orexins, feeding, and energy balance. Prog Brain Res 198:47-64. CrossRef Medline

Han MH, Kawasaki A, Wei JY, Barnstable CJ (2001) Miniature postsynaptic currents depend on $\mathrm{Ca} 2+$ released from internal stores via PLC/IP3 pathway. Neuroreport 12:2203-2207. Medline

Henningfield JE, Stapleton JM, Benowitz NL, Grayson RF, London ED (1993) Higher levels of nicotine in arterial than in venous blood after cigarette smoking. Drug Alcohol Depend 33:23-29. Medline 
Henny $P$, Jones BE (2006) Innervation of orexin/hypocretin neurons by GABAergic, glutamatergic or cholinergic basal forebrain terminals evidenced by immunostaining for presynaptic vesicular transporter and postsynaptic scaffolding proteins. J Comp Neurol 499: 645-661. CrossRef Medline

Hollander JA, Lu Q, Cameron MD, Kamenecka TM, Kenny PJ (2008) Insular hypocretin transmission regulates nicotine reward. Proc Natl Acad Sci U S A 105:19480-19485. CrossRef Medline

Huang H, Acuna-Goycolea C, Li Y, Cheng HM, Obrietan K, van den Pol AN (2007) Cannabinoids excite hypothalamic melaninconcentrating hormone but inhibit hypocretin/orexin neurons: implications for cannabinoid actions on food intake and cognitive arousal. J Neurosci 27:4870-4881. CrossRef Medline

Huang H, Xu Y, van den Pol AN (2011) Nicotine excites hypothalamic arcuate anorexigenic proopiomelanocortin neurons and orexigenic neuropeptide $Y$ neurons: similarities and differences. J Neurophysiol 106:1191-1202. CrossRef Medline

Lambe EK, Picciotto MR, Aghajanian GK (2003) Nicotine induces glutamate release from thalamocortical terminals in prefrontal cortex. Neuropsychopharmacology 28:216-225. CrossRef Medline

Léna C, Changeux JP (1997) Role of Ca2 + ions in nicotinic facilitation of GABA release in mouse thalamus. J Neurosci 17:576-585. Medline

Li Y, van den Pol AN (2006) Differential target-dependent actions of coexpressed inhibitory dynorphin and excitatory hypocretin/orexin neuropeptides. J Neurosci 26:13037-13047. CrossRef Medline

Li Y, Gao XB, Sakurai T, van den Pol AN (2002) Hypocretin/orexin excites hypocretin neurons via a local glutamate neuron-a potential mechanism for orchestrating the hypothalamic arousal system. Neuron 36:1169-1181. Medline

Liu ZW, Gan G, Suyama S, Gao XB (2011) Intracellular energy status regulates activity in hypocretin/orexin neurones: a link between energy and behavioural states. J Physiol 589:4157-4166. CrossRef Medline

Llano I, González J, Caputo C, Lai FA, Blayney LM, Tan YP, Marty A (2000) Presynaptic calcium stores underlie large-amplitude miniature IPSCs and spontaneous calcium transients. Nat Neurosci 3:1256-1265. CrossRef Medline

Mahler SV, Smith RJ, Moorman DE, Sartor GC, Aston-Jones G (2012) Multiple roles for orexin/hypocretin in addiction. Prog Brain Res 198:79-121. CrossRef Medline

Mansvelder HD, Keath JR, McGehee DS (2002) Synaptic mechanisms underlie nicotine-induced excitability of brain reward areas. Neuron 33:905-919. Medline

McCormack TJ, Melis C, Colón J, Gay EA, Mike A, Karoly R, Lamb PW, Molteni C Yakel JL (2010) Rapid desensitization of the rat alpha7 $\mathrm{nAChR}$ is facilitated by the presence of a proline residue in the outer beta-sheet. J Physiol 588:4415-4429. CrossRef Medline

Meyer EL, Xiao Y, Kellar KJ (2001) Agonist regulation of rat alpha 3 beta 4 nicotinic acetylcholine receptors stably expressed in human embryonic kidney 293 cells. Mol Pharmacol 60:568-576. Medline

Mileykovskiy BY, Kiyashchenko LI, Siegel JM (2005) Behavioral correlates of activity in identified hypocretin/orexin neurons. Neuron 46:787-798. CrossRef Medline

Morgan AJ, Harrod SB, Lacy RT, Stanley EM, Fadel JR (2013) Intravenous prenatal nicotine exposure increases orexin expression in the lateral hypothalamus and orexin innervation of the ventral tegmental area in adult male rats. Drug Alcohol Depend 132:562-570. CrossRef Medline

Muschamp JW, Hollander JA, Thompson JL, Voren G, Hassinger LC, Onvani S, Kamenecka TM, Borgland SL, Kenny PJ, Carlezon WA Jr (2014) Hypocretin (orexin) facilitates reward by attenuating the antireward effects of its cotransmitter dynorphin in ventral tegmental area. Proc Natl Acad Sci U S A 111:E1648-1655. CrossRef Medline

Neher E, Sakaba T (2008) Multiple roles of calcium ions in the regulation of neurotransmitter release. Neuron 59:861-872. CrossRef Medline
O'Hara BF, Edgar DM, Cao VH, Wiler SW, Heller HC, Kilduff TS, Miller JD (1998) Nicotine and nicotinic receptors in the circadian system. Psychoneuroendocrinology 23:161-173.

Paradiso KG, Steinbach JH (2003) Nicotine is highly effective at producing desensitization of rat alpha4beta2 neuronal nicotinic receptors. J Physiol 553:857-871. CrossRef Medline

Parikh V, Kozak R, Martinez V, Sarter M (2007) Prefrontal acetylcholine release controls cue detection on multiple timescales. Neuron 56:141-154. CrossRef Medline

Pasumarthi RK, Fadel J (2008) Activation of orexin/hypocretin projections to basal forebrain and paraventricular thalamus by acute nicotine. Brain Res Bull 77:367-373. CrossRef Medline

Pasumarthi RK, Reznikov LR, Fadel J (2006) Activation of orexin neurons by acute nicotine. Eur J Pharmacol 535:172-176. CrossRef Medline

Peyron C, Tighe DK, van den Pol AN, de Lecea L, Heller HC, Sutcliffe JG, Kilduff TS (1998) Neurons containing hypocretin (orexin) project to multiple neuronal systems. J Neurosci 18:9996-10015. Medline

Rao Y, Mineur YS, Gan G, Wang AH, Liu ZW, Wu X, Suyama S, de Lecea L, Horvath TL, Picciotto MR, Gao XB (2013) Repeated in vivo exposure of cocaine induces long-lasting synaptic plasticity in hypocretin/orexin-producing neurons in the lateral hypothalamus in mice. J Physiol 591:1951-1966. CrossRef Medline

Reitstetter R, Lukas RJ, Gruener R (1999) Dependence of nicotinic acetylcholine receptor recovery from desensitization on the duration of agonist exposure. J Pharmacol Exp Ther 289:656-660. Medline

Rose JE, Mukhin AG, Lokitz SJ, Turkington TG, Herskovic J, Behm FM, Garg S, Garg PK (2010) Kinetics of brain nicotine accumulation in dependent and nondependent smokers assessed with PET and cigarettes containing 11C-nicotine. Proc Natl Acad Sci U S A 107:5190-5195. CrossRef Medline

Sakurai T, Nagata R, Yamanaka A, Kawamura H, Tsujino N, Muraki Y, Kageyama H, Kunita S, Takahashi S, Goto K, Koyama Y, Shioda $S$, Yanagisawa M (2005) Input of orexin/hypocretin neurons revealed by a genetically encoded tracer in mice. Neuron 46:297308. CrossRef Medline

Sakurai T, Amemiya A, Ishii M, Matsuzaki I, Chemelli RM, Tanaka H, Williams SC, Richardson JA, Kozlowski GP, Wilson S, Arch JR, Buckingham RE, Haynes AC, Carr SA, Annan RS, McNulty DE, Liu WS, Terrett JA, Elshourbagy NA, Bergsma DJ, Yanagisawa M (1998) Orexins and orexin receptors: a family of hypothalamic neuropeptides and $G$ protein-coupled receptors that regulate feeding behavior. Cell 92:573-585.CrossRef

Sharma G, Grybko M, Vijayaraghavan S (2008) Action potentialindependent and nicotinic receptor-mediated concerted release of multiple quanta at hippocampal CA3-mossy fiber synapses. J Neurosci 28:2563-2575. CrossRef Medline

Südhof TC (2012) Calcium control of neurotransmitter release. Cold Spring Harb Perspect Biol 4:a011353CrossRef

van den Pol AN (1999) Hypothalamic hypocretin (orexin): robust innervation of the spinal cord. J Neurosci 19:3171-3182. Medline

Wada E, Wada K, Boulter J, Deneris E, Heinemann S, Patrick J, Swanson LW (1989) Distribution of alpha 2, alpha 3, alpha 4, and beta 2 neuronal nicotinic receptor subunit mRNAs in the central nervous system: a hybridization histochemical study in the rat. $J$ Comp Neurol 284:314-335.CrossRef

Wojcik SM, Rhee JS, Herzog E, Sigler A, Jahn R, Takamori S, Brose N, Rosenmund C (2004) An essential role for vesicular glutamate transporter 1 (VGLUT1) in postnatal development and control of quantal size. Proc Natl Acad Sci U S A 101:7158-7163. CrossRef Medline

Wu MF, John J, Maidment N, Lam HA, Siegel JM (2002) Hypocretin release in normal and narcoleptic dogs after food and sleep deprivation, eating, and movement. Am J Physiol Regul Integr Comp Physiol 283:R1079-R1086. CrossRef Medline

Zhou FM, Liang Y Dani JA (2001) Endogenous nicotinic cholinergic activity regulates dopamine release in the striatum. Nat Neurosci 4:1224-1229. CrossRef Medline 